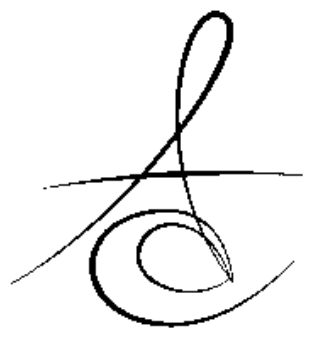

\title{
İKİ TARAFLI ALT BİRİNCİ BÜYÜK AZI DİŞİ EKSİKLİĞİNİN GEÇİCİ HAREKETLİ PROTEZ İLE TEDAVİSİ (VAKA RAPORU) ${ }^{\neq}$
}

TREATMENT OF BILATERAL FIRST MOLAR MISSING BY TEMPORARY REMOVABLE PARTIAL DENTURE (CASE REPORT) ${ }^{\neq}$

Uzm. Dt. Esra İNCESU*

\author{
Dr. Öğr. Üyesi Alper ÖZDOĞAN**
}

Makale Kodu/Article code: 2742

Makale Gönderilme tarihi: 29.03.2016

Kabul Tarihi; $\quad 07.04 .2016$

\section{öz}

Çürük ve periodontal hastalık gibi etkenlerden dolayı dişler kaybedilmekte ve bu kayıplardan en fazla birinci büyük azı dişleri etkilenmektedir. Birinci büyük azı dişinin eksikliği, çeneler arası ilişkiyi ve okluzyonu etkileyen önemli bir sorundur. Bu çalışmada iki taraflı birinci büyük azı dişini kaybetmiş 17 yaşındaki bir bayan hastaya yapılacak olan geçici protez türü sunulacaktır. Hastaya bu protez türüne karar vermede hangi kriterlerin rol aldığı ve ne tür bir protez yapıldığı literatürler eşliğinde anlatılacaktır. Hastaya yapılan geçici hareketli protez ile hasta memnuniyeti sağlandı. Anahtar Kelimeler: Diş kaybı, geçici hareketli protez

\section{GİRİŞ}

Dünyada yaygın olarak görülen sağlık sorunlarından biri de ağız ve diş sağı̆ğı ile ilgili sorunlardır. Kişilerin çoğu, yaşamları boyunca ağız ve diş sağılığı ile ilgili sorunlardan etkilenmektedir. ${ }^{1}{ }^{2} 2$ Toplumlarda yaygın olarak görülen eksik diş nedenlerinin çoğu çürük ve periodontal hastalıklardır. ${ }^{3}$ Bu nedenlere bağlı olarak da erken yaşta diş kayıpları görülmektedir. Diş kaybı; estetik, konuşma, çiğneme, beslenme ile ilgili problemler, sosyal ilişkilerde problemler ve hatta duygusal sorunlar nedeniyle kişinin yaşam kalitesini etkileyen bir durumdur. ${ }^{4-6}$

Birinci büyük azı dişleri; çeşitli nedenlerden dolayı, çürüğün ve erken çekimin en fazla görüldüğü dişlerdir. Bu nedenler arasında; erken yaşlarda ağız

\section{ABSTRACT}

Tooth missing depends on factors such as; caries and periodontal diseases. Early missing is especially seen at first molars because of several causes. Missing of first molar is an important issue, which affects the relationship between jaws and, the occlusion. The treatment by temporary partial denture of 17 year-old female patient who has bilateral first molar missing will be described in this study. Patients starring in deciding which of the criteria in this type of prosthesis and what type of prosthesis will be made as described by literature. The patient satisfaction was provided by temporary removable prosthesis.

Key Words: Missing teeth, temporary removable prosthesis.

ortamıyla temasa geçmeleri, erişkin olgunluğa erişememeleri, çocukların oral hijyen alışkanlıklarının yeterli olmaması, diş hekimleri ile iletişim eksikliği ve ebeveynlerin ilgi ve dikkat eksikliği sayılabilir. ${ }^{7}$ Birinci büyük azı dişler okluzyon ve çiğnemedeki en önemli dişlerden birisi olduğu için bu dişlerin erken kaybına bağlı olarak çiğneme performansında azalma, komşu dişlerde yer değişikliği, dişler arasında diastemaların oluşması gibi sorunlar ortaya çıkabilmektedir.

Birinci büyük azı dişlerinin erken yaşlarda kaybı bir takım konservatif ve ortodontik yaklaşımlarla tolere edilebilir ya da boşluk diğer dişlerle kapatılıp modifiye edilebilir. Ancak ilerleyen yaşlarda çürük ve diğer nedenlerle görülen diş kaybı, hastaları protetik restorasyonlar yaptırmaya yönlendirir. ${ }^{8}$ Başarııı veya kişiye uygun bir protetik restorasyon ise hastaya ait ağız içi

\footnotetext{
* Sakarya Ağız ve Diş Sağlığı Hastanesi, Sakarya

${ }^{* *}$ Atatürk Üniversitesi, Diş Hekimliği Fakültesi, Protetik Diş Tedavisi AD. Erzurum

₹ 18-20 Mart 2016 tarihinde Erzurum'da gerçekleştirilen, 5. Uluslararası Türk Prostodonti ve İmplantoloji Derneği (TPID) Palandöken Kış Sempozyumunda poster olarak sunulmuştur.
} 
ve sosyal tüm faktörler göz önüne alınarak doğru bir planlama yapılarak sağlanabilir. Bu olgunun tedavi planlamasında da tüm bu faktörler göz önüne alındı ve hastaya en uygun protezin yapılması amaçlandı.

\section{OLGU}

On yedi yaşındaki bayan hasta Atatürk Üniversitesi Diş Hekimliği Fakültesi Protetik Diş Tedavisi A.D. öğretim üyesi kliniğine, alt sağ ve sol çenesinde bulunan boşlukların geçici olarak kapatılması için başvurmuştur. Yapılan ağız içi ve radyografik inceleme sonucunda hastanın alt sağ ile sol birinci büyük azı dişlerinin eksik olduğu ve dişlerdeki hareketlenmelere bağı olarak yer kaybının başladığı tespit edildi (Resim $1,2)$.

Hastadan alınan anamnezde, her iki (2) büyük azı dişini de üç (3) yıl önce derin çürükler nedeniyle çektirdiği, ortodontik tedavi yaptırmak istemediği ve ileriki yıllarda yapılacak olan implant tedavisine kadar çekim boşluğunu korumak istediği bilgisine ulaşıldı.

Yapılan ağız içi incelemeler sonucunda hasta yaşı ve sosyoekonomik durum da göz önüne alınarak; hastaya kroşe ve metal içermeyen, iki taraflı birinci büyük azı dişlerine kadar uzayacak ve çift taraflı ark stabilizasyonu sağlayacak olan hareketli geçici bir protez yapılmasına karar verildi (Resim 3). İlk seansta, hastanın alt ve üst çenesinden irreversibl hidrokolloid ölçü maddesi (ALGINoplast; Heraeus Kulzer, Hanau, Almanya) ile ölçü alındı. Daha sonra bu ölçüden elde edilen model üzerinde alt çeneye baz plaktan (Cavex; Haarlem, Hollanda) kaide plağı uygulandı ve mum duvar hazırlanarak kapanış kaydı alındı. Çekim boşluğunun daralmış olmasından dolayı birinci büyük azı dişlerinin yerine alt çenenin her iki tarafına da küçük azı dişi dizilip hasta ağzında prova edildi. Yapılan tüm kontrollerden sonra protez muflaya alınıp ISI ile polimerize olan akrilik rezin (Meliodent; Heraus Kulzer, Hanau, Almanya) ile bitim işlemi yapıldı. Tesviye ve cila işlemlerinden sonra tamamlanmış protez (Resim 4) hasta ağzında kontak noktaları, protezin adaptasyonu, okluzal uyumlamalar yönünden kontrol edildi (Resim 5,6). Tedavi sonrası hasta, hareketli protezini nasıl kullanacağı, yaşanabilecek adaptasyon problemleri, temizlik ve oral hijyen yönünden bilgilendirildi.

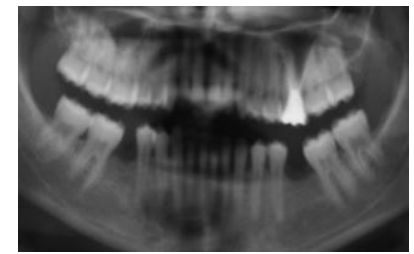

Resim 1. Eksik dişlerin radyografik görüntüsü

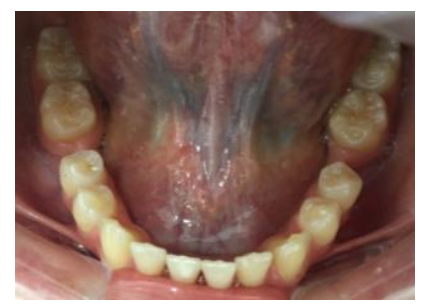

Resim 2. Hastanın başlangıçtaki ağız içi görüntüsü

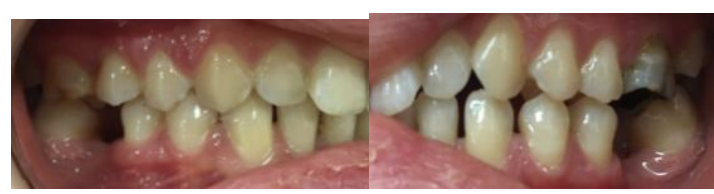

Resim 3. Hastanın başlangıçtaki ağız içi sağ ve sol kapanış profil görüntüsü

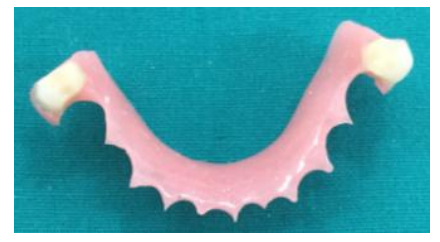

Resim 4. Bitmiş protezin görüntüsü

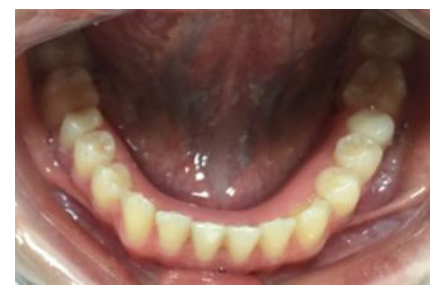

Resim 5.Yapılan protezin ağız içi görüntüsü

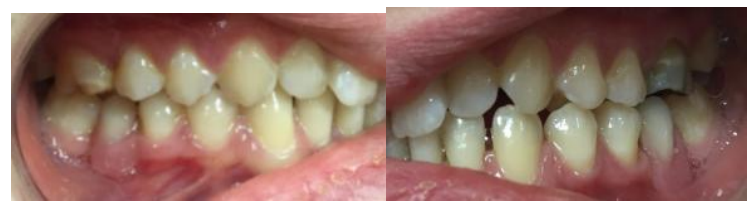

Resim 6. Yapılan protezin sağ ve sol kapanış profil görüntüsü 


\section{TARTIŞMA}

Kaybedilen dişlerin ve çevre dokuların fonksiyonel işlevlerinin geri kazandırılabilmesi ve normal biyolojik uyumlarını sürdürebilmesi için yapılan pek çok protez türü vardır. Sabit protez, kaybedilen dişlerin doğal diş, kök veya implantlardan destek alarak estetik, konuşma ve çiğneme fonksiyonlarını sağlayan ve destek dişlere yapıştırılan protez türüdür. ${ }^{9}$ Hareketli bölümlü protez ise mukozadan ve/veya doğal dişlerden destek alan doğal diş kayıpları ve ilgili dokuları restore eden apareylerdir. Bu protezler değişik fonksiyonları olan ve birbirleriyle belirli bir koordinasyon içinde çalışan parçalardan oluşur. ${ }^{10}$

Farklı nedenlerle kaybedilmiş diş eksikliklerinin tedavisinde uygun materyal ve tekniğin seçilmesinde hastanın genel sağlık ve ekonomik durumu, hastanın restorasyondan beklentisi, dişlerin büyüklüğü ve pozisyonu, destek dişler arası mesafe önem arz etmektedir. ${ }^{11}$ Hastamı ortodontik tedavi görmeyi kabul etmemiştir. Bu bölgeye sabit protez yapımı için dişlerinin kesilmesini istememiş ve ileriki yıllarda implant üstü bir protez yaptırmak istediğini bildirmiştir. Hastanın ekonomik durumunu da göz önüne alarak, çekim boşluklarının daha da kapanmasını önlemek ve hastayı ileriki bir daimi implant üstü proteze hazırlamak için maliyeti daha uygun olan akrilikten hazırlanmış geçici bir hareketli protez yapılması uygun görüldü.

Hareketli bölümlü protezlerdeki en büyük sorunlardan biri kroşelerin neden olduğu estetik sorunlardır. Böyle durumlarda klinisyen estetik kaygıları ortadan kaldırmak için kroşeleri maskeleme yönünde uygulamalar yapmaktadır. ${ }^{12}$ Hastanın yaşını ve estetik beklentisini de dikkate alarak yaptığımız geçici protezde kroşe kullanılmadı; tutuculuk ise hem iki taraflı ark stabilizasyonu hem de ön grup dişlerin lingualindeki undercut alanlardan faydalanarak sağlandı.

\section{SONUÇ}

Hastaya yapılan geçici hareketli protez ile komşu ve karşıt dişlerin yer değiştirmesi önlenmiş, çekim boşluğu ilerleyen yıllarda yapılması planlanan implant tedavisi için korunmuş, çiğneme performansı arttırılıp estetik sorunlar giderilerek hasta memnuniyeti sağlanmıştır.

Esra İncesu, ORCID ID: 0000-0001-8816-5456 Alper Özdoğan, ORCID ID: 0000-0003-0649-3056

\section{KAYNAKLAR}

1. Bertan M, Çağatay G. Halk sağlığı temel bilgiler. Güneş Kitabevi. Ankara. 1995.

2. Dirican R, Bilge N. Halk sağlığı-Toplum hekimliği, Uludağ Üniversitesi basımevi. 1993.

3. Loe $\mathrm{H}$. Oral hygiene in the prevention of caries and periodontal disease. Int Dent J 2000; 50: 129-39.

4. Haikola B, Oikarinen $K$, Soderholm AL, Remes-Lyly T, Sipila K. Prevalence of edentulousness and related factors among elderly Finns. J Oral Rehabil 2008; 35: 827-35.

5. Gilbert GH, Meng X, Duncan RP, Shelton BJ. Incidence of tooth loss and prosthodontic dental care: effect on chewing difficulty onset, a component of oral health-related quality of life. J Am Geriatr Soc 2004; 52: 880-5.

6. Haştar H, Yılmaz HH, Orhan H. Dişsiz yaşlı hastalarda panoramik radyografi bulguları. S.D.Ü. Sağlık Bil Ens Derg 2010;1:82-7.

7. Kırzıoğlu Z, Gök B. Birinci büyük azı dişi erken kaybı ve etkileri -derleme, Balıkesir Sağılk Bil Derg 2014; 1: 41-4.

8. Akın H, Tuğut F, Güney Ü, Akar $T$, Özdemir AK. Yaş, cinsiyet, eğitim durumu ve gelir düzeyinin, diş kaybı ve protetik tedaviler üzerindeki etkilerinin değerlendirilmesi, Cumhuriyet Dent J 2011;14:20410.

9. Oyar P. Sabit ve hareketli protezin yeniden yapımı ile estetik ve fonksiyonun iyileştirilmesi: Olgu sunumu Atatürk Üniv Diş Hek Fak Derg 2014;10812.

10. Can G, Akaltan F. Hareketli Bölümlü Protezler Planlama. Ankara, Ankara Basım Evi. 2002.

11. Doğan DO, Yeler T, Tugut F. Fiberle güçlendirilmiş kompozit köprü (vaka raporu). Cumhuriyet Dent J 2009;12:47-51.

12. İmren Ş, Özkan $P$, Gürbüz $A$. Hareketli bölümlü protezlerin kroşe planlanmasında estetik yaklaşımlar (Vaka Raporu). T Klin J Dent Sci 1998; 4:95-9.

\author{
Yazışma Adresi \\ Dr. Öğr. Üyesi Alper ÖZDOĞAN \\ Atatürk Üniversitesi \\ Diş Hekimliği Fakültesi, \\ Protetik Diş Tedavisi AD \\ Erzurum \\ TIf; 5392018440 \\ e-mail: alprozdgn@gmail.com
}

